\title{
Article \\ Factors Affecting Adult Captures of the Cotton Bollworm, Helicoverpa armigera (Hübner) (Lepidoptera: Noctuidae) in Pheromone-Baited Traps
}

\author{
Alkiviadis Karakasis, Evagelia Lampiri * (D), Christos I. Rumbos (1) and Christos G. Athanassiou (1) \\ Laboratory of Entomology and Agricultural Zoology, Department of Agriculture, \\ Crop Production and Rural Environment, University of Thessaly, 38446 Volos, Greece; \\ alkiviadiskarakasis@gmail.com (A.K.); crumbos@uth.gr (C.I.R.); athanassiou@uth.gr (C.G.A.) \\ * Correspondence: elampiri@agr.uth.gr; Tel.: +30-242-109-3195; Fax: +30-242-109-3178
}

\section{check for}

updates

Citation: Karakasis, A.; Lampiri, E.; Rumbos, C.I.; Athanassiou, C.G. Factors Affecting Adult Captures of the Cotton Bollworm, Helicoverpa armigera (Hübner) (Lepidoptera: Noctuidae) in Pheromone-Baited Traps. Agronomy 2021, 11, 2539. https: / / doi.org/10.3390/ agronomy11122539

Academic Editor: Andrea Liliana Clavijo McCormick

Received: 22 November 2021 Accepted: 10 December 2021 Published: 14 December 2021

Publisher's Note: MDPI stays neutral with regard to jurisdictional claims in published maps and institutional affiliations.

Copyright: (c) 2021 by the authors. Licensee MDPI, Basel, Switzerland. This article is an open access article distributed under the terms and conditions of the Creative Commons Attribution (CC BY) license (https:/ / creativecommons.org/licenses/by/ $4.0 /)$.
Abstract: The effects of funnel-trap color, trap height and pheromone formulation on the adult captures of the cotton bollworm, Helicoverpa armigera (Hübner) (Lepidoptera: Noctuidae) were evaluated in traps that were suspended in cotton fields in central Greece. Briefly, in a first trial, the efficacy of funnel traps of three different colors, i.e., green, striped (with black and white stripes) and white, was comparatively evaluated, whereas in a second trial green funnel traps were placed at three heights, i.e., 30,60 and $90 \mathrm{~cm}$ from the ground. Finally, in a third trial we tested the efficiency of green funnel traps with three commercially available pheromone lures. Considering the overall captures, trap color and pheromone formulation affected male captures, whereas trap height had no influence. Captures notably increased in all traps from late August to mid-September. In total, the white funnel trap captured more moths than the green or striped funnel traps. Placement of the traps at different heights did not significantly affect captures, but seasonal differences were observed at individual dates during the trapping period. Barrettine's pheromone lure provided significantly more captures than the other two (Russell, Trécé) in some of the trap-check dates. The results can be further utilized in the monitoring protocols of H. armigera in cotton fields.

Keywords: Helicoverpa armigera; cotton; pheromone traps; monitoring; funnel traps

\section{Introduction}

The cotton bollworm, Helicoverpa armigera (Hübner) (Lepidoptera: Noctuidae), is an economically serious pest with a wide host range comprising more than 180 cultivated and wild plant species [1]. Some of the high-value crops that are infested by this species are cotton, maize, tobacco, sunflower, sorghum, soybeans, pulses, rapeseed, safflower and groundnuts [1-6]. The number of generations of this particular insect varies from 1 per year in cold climates up to 11 generations per year in the tropics [1,7]. In northern Greece, H. armigera completes two or three generations per year, while for the rest of Greece the available data are inconclusive [8].

The larvae of this species feed on all the reproductive and vegetative parts of cotton, showing a special preference to buds and bolls due to the high concentration of oxygen in these plant parts [1,9]. The larval feeding behavior can either trigger the buds to bloom prematurely, preventing fruiting, or cause the fall of the bolls and the deterioration of the fiber [1]. All of the above lead to significant production losses and to high control costs that exceed $\$ 5$ million per year globally $[10,11]$. Furthermore, this species has developed a considerable level of resistance to many groups of insecticides such as pyrethroids, organophosphate and carbamate [12-15]. Nonetheless, some groups of insecticides such as spinosyns, diamides and growth regulators have shown encouraging results against the cotton bollworm [16-18]. The adult population of $H$. armigera in cotton, but also in other crops, is successfully monitored mainly by pheromone-baited traps and capture 
numbers are used to time the insecticidal applications [11,19-21]. The chemical structure of the female sex pheromone of $H$. armigera was identified as a (Z)-11-hexadecenal and (Z)-9-hexadecenal in a 97:3 ratio [22]. This sex pheromone is used in pheromone traps, which can be used both for monitoring the insect population, as well as for mass trapping with good results [23-29].

There is a wide variety of pheromone-baited traps that vary in design, size and other visual stimuli such as the color of the trapping surface, depending on the target insect species [24-26,28,29]. The results of several studies have shown that the trap color significantly affects the capture efficacy of a trap for several moth species of economic importance [23-28]. For example, Athanassiou et al. [26] evaluated the efficacy of four different-colored pheromone traps for the monitoring of adults of the pine processionary moth, Thaumetopoea pityocampa (Denis \& Schiffermüller) (Lepidoptera: Thaumetopoeidae), and reported that white- and yellow-colored traps caught significantly more males than the brown- and green-colored traps in high-density pine stands. In another study, Hashemi [30] observed that the highest captures of adults of the potato tuber moth, Phthorimaea operculella (Zeller) (Lepidoptera: Gelechiidae), were recorded in green traps compared to the red and yellow ones. Nevertheless, there is still inadequate information on this subject in the case of adult captures of $H$. armigera.

Apart from the characteristics of the traps, other factors that affect the capture rate in pheromone traps are the trap placement, the pheromone source and the trapping location $[24,26,27,30]$. There are a number of studies on the impact of the height at which the trap is placed on the number of captures of several insect species [27,29-33]. Kavallieratos et al. [27] reported that trap height had no influence on the adult male captures of the olive moth, Prays oleae (Bernard) (Lepidoptera: Yponomeutidae), in olive orchards. Witzgall et al. [32] found that the traps that were placed at a height of $3.0 \mathrm{~m}$ above the ground level captured the highest number of $H$. armigera adult males in pigeon-pea crops, compared with the traps placed at a height of 1.5 and $2.0 \mathrm{~m}$. Considering the above, it becomes evident that, even if the same trapping device and pheromone lure is used, the way that the traps are suspended may notably differentiate the number of captures, resulting in different decision making in relation to control measures [34].

Another important factor that affects the trap captures is the type of the lure that is used. Apparently, different pheromone attractants have different insect-trapping capacities [25,35,36]. Adams et al. [35] reported significant differences in the capturing efficiency of four commercially available sex pheromone lures for adults of the fall armyworm, Spodoptera frugiperda (J.E. Smith) (Lepidoptera: Noctuidae). Similarly, differences were observed when testing various commercially available pheromone lures for the corn earworm, Helicoverpa zea (Boddie) (Lepidoptera: Noctuidae) [36]. Even in similar quantities of the pheromone, the way that the pheromone is loaded can drastically affect captures, as has been shown in the case of the jasmine moth, Palpita unionalis (Hübner) (Lepidoptera: Pyralidae) [25].

Although Greece is the European Union's main cotton producer, accounting for over $80 \%$ of the total European production [37], few published studies are available regarding the monitoring of $H$. armigera adults using pheromone-baited traps, although they are the major cotton pests in Greece [8,38,39]. In a study conducted from 2002 to 2005 in 10 areas of the prefecture of Larissa in Thessaly, a negative correlation was found between the number of trapped males of H. armigera and the cotton production for each year [39]. Still, the data are scarce in the case of the population fluctuation of this species in the other prefectures of Thessaly, Greece, which is the main cotton-producing area of the country. In this context, the objective of the present study was to investigate the effects of trap color, trap height, and pheromone formulation on the capture of H. armigera in the prefecture of Magnesia, Thessaly, in an effort to contribute further towards the use of standardized trapping protocols. 


\section{Materials and Methods}

\subsection{Experimental Site}

The experiments were carried out in the region of Velestino (Magnesia, Thessaly, Central Greece) during the 2018 growing season. Velestino is located at an altitude of $120 \mathrm{~m}$ and its longitude and latitude are $22^{\circ} 44^{\prime}$ and $39^{\circ} 24^{\prime}$, respectively. The area was chosen due to the presence of large cotton fields. The sowing of cotton was done in mid-April, followed by standard cultivation care, whereas the trapping period was initiated in early June and terminated in late September, 2018. The minimum and maximum temperatures during the experimental period in the area of Velestino were 16.2 and $31.8^{\circ} \mathrm{C}$ in June, 18.4 and $37.4{ }^{\circ} \mathrm{C}$ in July, 21.3 and $37.2{ }^{\circ} \mathrm{C}$ in August and 14.7 and $31.9^{\circ} \mathrm{C}$ in September, while rainfall was 113.4, 19.4, 14.2 and $52.0 \mathrm{~mm}$ in June, July, August and September, respectively. Table 1 presents the climatic data at time intervals between observations. These data were collected by a local meteorological station.

Table 1. The average temperature $\left({ }^{\circ} \mathrm{C}\right)$, rainfall $(\mathrm{mm})$ and wind speed $(\mathrm{km} / \mathrm{h})$ in the area of Velestino at intervals between observations of pheromone traps.

\begin{tabular}{ccccc}
\hline Date & No of Observation & $\begin{array}{c}\text { Average } \\
\text { Temperature }\left({ }^{\circ} \mathbf{C}\right)\end{array}$ & Average Rainfall (mm) & $\begin{array}{c}\text { Average Wind } \\
\text { Speed }(\mathbf{k m} / \mathbf{h})\end{array}$ \\
\hline 6 June (installation)-13 June & 1 & 25.6 & 0.1 & 7.6 \\
13 June-22 June & 2 & 24.4 & 1.9 & 6.9 \\
22 June-18 July & 3 & 25.1 & 4.0 & 7.3 \\
18 July-25 July & 4 & 27.8 & 0.0 & 8.7 \\
25 July-1 August & 5 & 26.9 & 6.8 & 4.3 \\
1 August-8 August & 6 & 27.6 & 1.7 & 4.6 \\
8 August-16 August & 7 & 27.1 & 0.0 & 4.2 \\
16 August-23 August & 8 & 27.9 & 0.0 & 5.9 \\
23 August-29 August & 9 & 26.3 & 4.1 & 5.6 \\
29 August-6 September & 10 & 27.3 & 0.0 & 4.8 \\
6 September-12 September & 11 & 26.5 & 0.0 & 7.5 \\
12 September-21 September & 12 & 23.9 & 0.1 & 4.9 \\
21 September-29 September & 13 & 20.6 & 0.3 & 5.6 \\
\hline
\end{tabular}

\subsection{Trapping Devices and Pheromones}

There were three series of field experiments. In the first series, we used funnel traps of three different colors, i.e., green, striped (with black and white stripes) and white (Hellapharm, Attica, Greece). All traps were suspended with their lowest part at $90 \mathrm{~cm}$ from the ground level. In the second series, we evaluated the height of the traps, by placing green funnel traps at three heights, i.e., at 30,60 and $90 \mathrm{~cm}$ from the ground. Barrettine's pheromone lure (Barrettine Environmental Health, Bristol, UK) was used in both series of experiments. Finally, in the third series, we used green funnel traps that were placed at $90 \mathrm{~cm}$ from the ground, with three commercially available pheromone lures, obtained from Barrettine (Barrettine Environmental Health, Bristol, UK), Russell (Russell IPM, Deeside, UK) and Trécé (Trécé, Inc., Adair, IA, USA). A paper that was saturated with the insecticide transfluthrin $(0.4 \% w / w$, VAPONA, Sarantis SA, Athens, Greece) was placed inside each trap and used as a killing agent.

\subsection{Trap Set Up}

The installation of the traps took place on June 6, 2018. In all cases, there were three replicates for each treatment $(3 \times 3=9$ traps/treatment). The traps were set on a cotton plot at a distance of $20 \mathrm{~m}$ from each other. The traps were placed in 9 parallel rows, where the first 3 rows corresponded to the factor with a specific color (green, white, striped), the next 3 rows to the factor of trap placement height $(30,60$ and $90 \mathrm{~cm})$ and the last 3 to factor different pheromone formulations (Barrettine, Russell, Trécé). The traps were inspected at weekly intervals by recording the number of $H$. armigera adults that were captured. There 
were 13 trap-check dates in total. After each inspection, all of the adults were removed and the traps were rotated in order to minimize the influence of the individual trapping location [24]. The pheromone lures were replaced every four weeks.

\subsection{Statistical Analysis}

Prior to analysis, all data were tested for normalization and homogeneity using either Levene's or O'Brien's test. Then, separately for each test, the data were submitted to a twoway ANOVA for each factor (trap color, trap height or pheromone) and trap-check date. For the comparison of the means, the Tukey-Kramer (HSD) test was used at 0.05 significant level. Moreover, in order to evaluate the 'synchronization' between pairs of catches among different trap items (traps with different characteristics) on the same date, the correlation coefficient values were calculated. These values were tested for their departure from zero by using a two-tailed $t$-test, at $\mathrm{n}-2 \mathrm{df}$ and at 0.01 significant level.

\section{Results}

\subsection{Effect of Trap Color}

All of the main effects (trap color and trap-check date) and their associated interactions were significant (Table 2). The white traps caught the highest number of H. armigera adults with an average of 17 individuals per trap compared to the green and striped traps with five and four adults per trap, respectively (Table 3). There were no significant differences between the green and striped traps regarding the total number of captures for any of the trap-check dates that were tested (Table 3). In the first measurements in June and July, the number of captures was low and did not exceed an average of two adults per trap (Table 3). In August, the captures were increased and in September they peaked for all of the traps. In the first three trap-check dates of September, significant differences were recorded between the white and the two other trap colors (Table 3).

Table 2. ANOVA parameters for trap color and trap-check dates (total df (degrees of freedom) $=116)$, $\mathrm{F}=$ ratio of two variables.

\begin{tabular}{cccc}
\hline Effects & df & F & $p$ \\
\hline Trap color & 2 & 23.4 & $<0.01$ \\
Date & 12 & 17.0 & $<0.01$ \\
Trap color $\times$ Date & 24 & 3.2 & $<0.01$ \\
\hline
\end{tabular}

Table 3. Mean number $( \pm \mathrm{SE})$ of Helicoverpa armigera adults per trap captured in each trap color and each trap-check date.

\begin{tabular}{|c|c|c|c|c|c|}
\hline Date & Green & White & Striped & $\mathbf{F}$ & $p$ \\
\hline 13 June 2018 & $0.00 \pm 0.00$ & $0.00 \pm 0.00$ & $0.33 \pm 0.33$ & 1.00 & 0.42 \\
\hline 22 June 2018 & $0.00 \pm 0.00$ & $0.00 \pm 0.00$ & $0.00 \pm 0.00$ & - & - \\
\hline 18 July 2018 & $0.66 \pm 0.33 \mathrm{a}$ & $1.00 \pm 0.00 b$ & $0.00 \pm 0.00 \mathrm{a}$ & 7.00 & $<0.05$ \\
\hline 25 July 2018 & $0.00 \pm 0.00$ & $2.33 \pm 1.85$ & $0.66 \pm 0.66$ & 1.11 & 0.38 \\
\hline 1 August 2018 & $0.66 \pm 0.33$ & $6.66 \pm 5.23$ & $1.00 \pm 1.00$ & 1.19 & 0.36 \\
\hline 8 August 2018 & $0.66 \pm 0.66$ & $11.00 \pm 10.50$ & $0.66 \pm 0.33$ & 0.96 & 0.43 \\
\hline 16 August 2018 & $1.00 \pm 0.57$ & $13.66 \pm 13.16$ & $0.66 \pm 0.33$ & 0.94 & 0.43 \\
\hline 23 August 2018 & $3.66 \pm 1.66$ & $17.33 \pm 13.90$ & $4.00 \pm 3.05$ & 0.88 & 0.46 \\
\hline 29 August 2018 & $3.33 \pm 1.20$ & $21.33 \pm 16.89$ & $4.33 \pm 1.85$ & 1.05 & 0.40 \\
\hline 6 September 2018 & $25.66 \pm 6.96 a$ & $61.33 \pm 11.17 b$ & $14.33 \pm 5.69 \mathrm{a}$ & 8.77 & $<0.05$ \\
\hline 12 September 2018 & $23.66 \pm 0.33 a$ & $78.00 \pm 11.53 \mathrm{~b}$ & $20.66 \pm 6.33 a$ & 8.03 & $<0.05$ \\
\hline 21 September 2018 & $1.33 \pm 1.33 \mathrm{a}$ & $9.33 \pm 1.20 b$ & $3.33 \pm 0.88 \mathrm{a}$ & 13.00 & $<0.05$ \\
\hline 29 September 2018 & $0.00 \pm 0.00$ & $0.00 \pm 0.00$ & $0.00 \pm 0.00$ & - & - \\
\hline Total average & $4.66 \pm 1.47 \mathrm{a}$ & $17.07 \pm 4.35 \mathrm{~b}$ & $3.84 \pm 1.15 \mathrm{a}$ & 7.33 & $<0.05$ \\
\hline
\end{tabular}

Within each date, means followed by the same letter were not significantly different (in all cases $\mathrm{df}=2,8$ ). Where no letters exist, no significant differences were noted. For the 1st observation 'Brien test was: $\mathrm{F}=1.7, p=0.247$ for the 3rd was: $\mathrm{F}=1.7, p=0.247$, for the 4 th was: $\mathrm{F}=1.5, p=0.286$, for the 5th was: $\mathrm{F}=1.7, p=0.259$, for the 6th was: $\mathrm{F}=1.7, p=0.249$, for the 7th was: $\mathrm{F}=1.7, p=0.248$, for the 8th was: $\mathrm{F}=1.6, p=0.265$, for the 9th was: $\mathrm{F}=1.7, p=0.252$. The unreported observations meet the criteria of the Levene's test. 
In more than $5 \%$ of the total observations, adult captures in the white traps exceeded 50 individuals per trap, in contrast to the other two traps for which captures did not exceed 26 moths per trap at any of the trap-check dates (Table 4). Furthermore, more than 16\% of the green and striped traps captured no adults, while the respective figure for white traps was much lower (Table 4). Finally, a positive and significant correlation coefficient was recorded between the white and green and the white and stripped traps, but not between the green and striped traps (Table 5).

Table 4. Detection sensitivity and capture rates for each trap color.

\begin{tabular}{cccc}
\hline & \multicolumn{2}{c}{$\%$ of Total Observations in Each Trap Color } \\
\hline Number of Adult Captures & Green & White & Striped \\
\hline 0 & 16.2 & 10.3 & 16.2 \\
$1-10$ & 12.0 & 12.8 & 12.8 \\
$11-50$ & 5.1 & 5.1 & 4.2 \\
$51-100$ & 0 & 5.1 & 0 \\
$>100$ & 0 & 0 & 0 \\
\hline
\end{tabular}

Table 5. Correlation coefficient values for pairs of $H$. armigera captures between traps with different colors.

\begin{tabular}{ccccc}
\hline Trap Color & $\mathbf{R}$ & $\mathbf{d f}$ & $\mathbf{t}$ & $\boldsymbol{p}$ \\
\hline Green-White & 0.78 & 38 & 3.754 & 0.001 \\
Green-Striped & 0.86 & 38 & 1.121 & 0.270 \\
White-Striped & 0.63 & 38 & 3.571 & 0.001 \\
\hline
\end{tabular}

\subsection{Effect of Trap Height}

Considering the overall data, trap height was not significant (Table 6). Considering each trap-check date, no significant differences were recorded among the traps that had been placed at different heights, with the exception of August 8, when captures by the traps at $30 \mathrm{~cm}$ differed significantly from the respective figures for the other two heights, and of September 21, when the traps at $60 \mathrm{~cm}$ differed from the other two heights (Table 7). As in the case of trap color, the highest captures were recorded late in the experimental period (Table 7).

Table 6. ANOVA parameters for trap height and trap-check dates (total $\mathrm{df}=116$ ).

\begin{tabular}{cccc}
\hline Effects & df & F & $p$ \\
\hline Trap height & 2 & 1.4 & 0.24 \\
Date & 12 & 7.1 & $<0.01$ \\
Trap height $\times$ Date & 24 & 0.5 & 0.96 \\
\hline
\end{tabular}

Table 7. Mean number $( \pm \mathrm{SE})$ of Helicoverpa armigera adults per trap captured in each trap height and each trap-check date.

\begin{tabular}{|c|c|c|c|c|c|}
\hline Date & $30 \mathrm{~cm}$ & $60 \mathrm{~cm}$ & $90 \mathrm{~cm}$ & F & $p$ \\
\hline 13 June 2018 & $0.33 \pm 0.33$ & $0.00 \pm 0.00$ & $0.00 \pm 0.00$ & 1.00 & 0.42 \\
\hline 22 June 2018 & $0.00 \pm 0.00$ & $0.00 \pm 0.00$ & $0.00 \pm 0.00$ & - & - \\
\hline 18 July 2018 & $2.33 \pm 1.45$ & $0.66 \pm 0.33$ & $1.66 \pm 0.88$ & 0.70 & 0.53 \\
\hline 25 July 2018 & $0.33 \pm 0.33$ & $0.66 \pm 0.66$ & $0.00 \pm 0.00$ & 0.60 & 0.57 \\
\hline 1 August 2018 & $0.00 \pm 0.00$ & $0.33 \pm 0.33$ & $0.00 \pm 0.00$ & 1.00 & 0.42 \\
\hline 8 August 2018 & $1.66 \pm 0.33 \mathrm{a}$ & $0.00 \pm 0.00 \mathrm{~b}$ & $0.33 \pm 0.33 b$ & 10.50 & $<0.01$ \\
\hline 16 August 2018 & $1.00 \pm 0.0$ & $0.66 \pm 0.33$ & $0.33 \pm 0.33$ & 1.50 & 0.29 \\
\hline 23 August 2018 & $0.66 \pm 0.33$ & $5.00 \pm 5.00$ & $2.00 \pm 1.15$ & 0.55 & 0.59 \\
\hline 29 August 2018 & $1.66 \pm 0.33$ & $3.33 \pm 2.84$ & $2.00 \pm 0.57$ & 0.27 & 0.77 \\
\hline
\end{tabular}


Table 7. Cont.

\begin{tabular}{|c|c|c|c|c|c|}
\hline Date & $30 \mathrm{~cm}$ & $60 \mathrm{~cm}$ & $90 \mathrm{~cm}$ & $\mathbf{F}$ & $p$ \\
\hline 6 September 2018 & $9.00 \pm 6.50$ & $21.66 \pm 11.31$ & $17.00 \pm 6.00$ & 0.59 & 0.58 \\
\hline 12 September 2018 & $7.00 \pm 4.50$ & $16.33 \pm 10.72$ & $8.66 \pm 2.60$ & 0.52 & 0.61 \\
\hline 21 September 2018 & $0.00 \pm 0.00 \mathrm{a}$ & $2.00 \pm 0.57 b$ & $0.00 \pm 0.00 \mathrm{a}$ & 12.00 & $<0.01$ \\
\hline 29 September 2018 & $0.00 \pm 0.00$ & $0.00 \pm 0.00$ & $0.00 \pm 0.00$ & - & - \\
\hline Total average & $1.84 \pm 0.68$ & $3.89 \pm 1.51$ & $2.46 \pm 0.88$ & 0.93 & 0.39 \\
\hline
\end{tabular}

Within each date, means followed by the same letter were not significantly different (in all cases $\mathrm{df}=2,8$ ). Where no letters exist, no significant differences were noted. For the 1st observation 'Brien test was: $\mathrm{F}=1.7, p=0.247$, for the 4th was: $\mathrm{F}=1.3, p=0.325$, for the 5th was: $\mathrm{F}=1.7, p=0.247$, for the 6th was: $\mathrm{F}=0.8, p=0.459$, for the 7th was: $\mathrm{F}=0.8, p=0.459$, for the 8th was: $\mathrm{F}=1.6, p=0.264$, for the 9th was: $\mathrm{F}=1.6, p=0.263$. The unreported observations meet the criteria of the Levene's test.

Additionally, none of the traps in these series of tests captured over 50 adults/trap, and in general, their detection sensitivity was comparable (Table 8). Finally, correlation coefficients were not significant for any of the trap pairs (Table 9).

Table 8. Detection sensitivity and capture rates for each trap height.

\begin{tabular}{cccc}
\hline & \multicolumn{3}{c}{$\%$ of Total Observations in Each Trap Height } \\
\hline Number of Adult Captures & $\mathbf{3 0} \mathbf{~ c m}$ & $\mathbf{6 0} \mathbf{~ c m}$ & $\mathbf{9 0} \mathbf{~ c m ~}$ \\
\hline 0 & 15.3 & 17.9 & 20.5 \\
$1-10$ & 16.2 & 11.1 & 9.4 \\
$11-50$ & 1.7 & 4.2 & 3.4 \\
$51-100$ & 0 & 0 & 0 \\
$>100$ & 0 & 0 & 0 \\
\hline
\end{tabular}

Table 9. Correlation coefficient values for pairs of H. armigera catches in traps suspended at different trap heights.

\begin{tabular}{ccccc}
\hline Trap Height & $\mathbf{R}$ & df & $\mathbf{t}$ & $\boldsymbol{p}$ \\
\hline $30 \mathrm{~cm}-60 \mathrm{~cm}$ & 0.65 & 38 & -1.730 & 0.092 \\
$30 \mathrm{~cm}-90 \mathrm{~cm}$ & 0.81 & 38 & -1.195 & 0.240 \\
$60 \mathrm{~cm}-90 \mathrm{~cm}$ & 0.61 & 38 & 1.197 & 0.239 \\
\hline
\end{tabular}

\subsection{Effect of Pheromone Formulations}

Both of the main effects (pheromone formulation and trap-check date) and their interactions were significant (Table 10). The Barrettine pheromone formulation collected the highest $H$. armigera adult numbers per trap, which was significantly higher than the respective figures for the other two formulations (Table 11). Early in the trapping period, as in the case of the previous tests, the number of captures was low, and comparable for all three formulations (Table 11). The traps that contained the Barrettine formulation peaked on 6 September with 25 adults/trap, while for the other two traps the peak was recorded on 23 August, with four and four adults/trap for Russell and Trécé, respectively.

Table 10. ANOVA parameters for pheromone formulation and trap-check dates (total $\mathrm{df}=116$ ).

\begin{tabular}{cccc}
\hline Effects & df & F & $p$ \\
\hline Pheromone & 2 & 17.6 & $<0.01$ \\
formulation & 12 & 7.1 & $<0.01$ \\
Date & 24 & 7.1 & $<0.01$ \\
Pheromone & & & \\
formulation $\times$ Date & &
\end{tabular}


Table 11. Mean number $( \pm \mathrm{SE})$ of Helicoverpa armigera adults per trap captured in each pheromone formulation and each trap-check date.

\begin{tabular}{|c|c|c|c|c|c|}
\hline Date & Barrettine & Russell & Trécé & $\mathbf{F}$ & $p$ \\
\hline 13 June 2018 & $0.00 \pm 0.00$ & $0.00 \pm 0.00$ & $1.33 \pm 1.33$ & 1.00 & 0.42 \\
\hline 22 June 2018 & $0.00 \pm 0.00$ & $0.00 \pm 0.00$ & $0.33 \pm 0.33$ & 1.00 & 0.42 \\
\hline 18 July 2018 & $1.00 \pm 0.57$ & $1.33 \pm 0.88$ & $1.66 \pm 0.88$ & 0.17 & 0.84 \\
\hline 25 July 2018 & $0.33 \pm 0.33$ & $0.00 \pm 0.00$ & $1.33 \pm 1.33$ & 0.76 & 0.50 \\
\hline 1 August 2018 & $1.66 \pm 0.88$ & $1.00 \pm 1.00$ & $1.33 \pm 0.66$ & 0.15 & 0.86 \\
\hline 08 August 2018 & $0.33 \pm 0.33$ & $0.00 \pm 0.00$ & $2.33 \pm 1.45$ & 2.15 & 0.19 \\
\hline 16 August 2018 & $1.00 \pm 0.57$ & $1.33 \pm 0.33$ & $0.33 \pm 0.33$ & 1.40 & 0.31 \\
\hline 23 August 2018 & $5.66 \pm 2.18$ & $4.33 \pm 2.18$ & $4.00 \pm 0.00$ & 0.24 & 0.79 \\
\hline 29 August 2018 & $4.66 \pm 1.66$ & $3.66 \pm 2.02$ & $2.00 \pm 0.57$ & 0.75 & 0.51 \\
\hline 6 Semptember 2018 & $25.33 \pm 3.66 \mathrm{a}$ & $0.66 \pm 0.66 b$ & $0.00 \pm 0.00 \mathrm{~b}$ & 45.02 & $<0.01$ \\
\hline 12 Semptember 2018 & $16.66 \pm 8.29$ & $1.00 \pm 1.00$ & $0.33 \pm 0.33$ & 3.66 & 0.09 \\
\hline 21 Semptember 2018 & $3.33 \pm 1.76$ & $0.00 \pm 0.00$ & $2.00 \pm 0.57$ & 2.45 & 0.16 \\
\hline 29 Semptember 2018 & $0.00 \pm 0.00$ & $0.00 \pm 0.00$ & $0.00 \pm 0.00$ & & \\
\hline Total average & $4.61 \pm 1.35 \mathrm{a}$ & $1.02 \pm 0.31 b$ & $1.36 \pm 0.28 b$ & 5.33 & $<0.01$ \\
\hline
\end{tabular}

Within each date, means followed by the same letter were not significantly different (in all cases $\mathrm{df}=2,8$ ). Where no letters exist, no significant differences were noted. For the 1st observation $\mathrm{O}^{\prime}$ Brien test was: $\mathrm{F}=1.7, p=0.247$, for the 2nd observation $\mathrm{O}^{\prime}$ Brien test was: $\mathrm{F}=1.7, p=0.247$, for the 4th was: $\mathrm{F}=1.6, p=0.265$, for the 8th was: $\mathrm{F}=0.8, p=0.459$, for the 10th was: $\mathrm{F}=1.7, p=0.256$, for the 11th was: $\mathrm{F}=1.7, p=0.252$, for the 12th was: $\mathrm{F}=1.5, p=0.279$. The unreported observations meet the criteria of the Levene's test.

The traps that were baited with the Barrettine lures were the only ones that captured 10-50 adults/trap (Table 12). Finally, the correlation coefficients' values were generally lower than those of the previous tests, and were not significant except for Russell and Trécé (Table 13).

Table 12. Detection sensitivity and capture rates for each trap baited pheromone formulation.

\begin{tabular}{cccc}
\hline & \% of total Observations in Each Pheromone Formulation \\
\hline Number of Adult Captures & Barrettine & Russell & Trécé \\
\hline 0 & 14.5 & 23.0 & 16.2 \\
$1-10$ & 14.5 & 10.2 & 17.0 \\
$11-50$ & 4.2 & 0 & 0 \\
$51-100$ & 0 & 0 & 0 \\
$>100$ & 0 & 0 & 0 \\
\hline
\end{tabular}

Table 13. Correlation coefficient values for pairs of $H$. armigera catches among traps baited with different pheromone formulations.

\begin{tabular}{ccccc}
\hline Pheromone Formulation & $\mathbf{R}$ & $\mathbf{d f}$ & $\mathbf{t}$ & $\boldsymbol{p}$ \\
\hline Barrettine-Russell & -0.03 & 38 & 2.571 & 0.014 \\
Barrettine-Trécé & -0.10 & 38 & 2.363 & 0.023 \\
Russell-Trécé & 0.21 & 38 & -0.788 & 0.436 \\
\hline
\end{tabular}

\section{Discussion}

In a previous work in cotton fields in Makedonia, Northern Greece during the 2005 and 2006 growing period, Mironidis et al. [8] used pheromone-baited funnel traps to monitor the H. armigera male activity. They recorded three peaks of male captures for 2005 (late July, late August and mid-September) and two for 2006 (late July and late August), suggesting that there were three or four generations of $H$. armigera per year in this region [8]. Our data showed a more uniform fluctuation in the area of Magnesia, with a longer single-peak period, starting from late August and lasting until mid-September. Similar results, in terms of captures that are concentrated in a relatively short period, have also been found in other surveys in several countries, such as Australia [23,40], Tanzania [41] and India [21,42]. For instance, Baker et al. [40] found that the highest number of captures in New South Wales, Australia, was reached at the end of the summer. In the work of Nyambo [41], 
the variation of the population of adults of H. armigera, as well as the level of infestation, were characterized by intense seasonality and were also influenced by the location of the experiment.

During the entire experimental period, between 13 June and 29 September, the white traps captured more $H$. armigera adults than the other two trap colors. The above results are consistent with many studies concerning either $H$. armigera [23] or other Lepidopteran species [24-28]. In a study that was conducted in Australia for the evaluation of various traps for the estimation of the H. armigera population, Sage and Gregg [23] found that the conical trap Texas with white plastic mesh (Albany International Corp. Needham Heights. Massachusetts) was the one that captured the most adults compared to the modified Texas with the gray plastic screen. Similarly, in an experiment that took place in two regions of Greece, Athanassiou et al. [25] showed that the white funnel traps captured the most adult males of the P. unionalis, in relation to brown, green and yellow funnel traps. The preference to the white trap color has been attributed to the fact that the reflective energy of the white color $(370-450 \mathrm{~nm})$ is higher than that of the other two trap colors used $[25,26]$. The highreflectance energy colors help males to locate the pheromone source, at least during the first interval of their activity when there is some light. This means that, at least at this stage, the pheromonal stimulus coexists with a visual stimulus and males may respond to both cues. Kelber et al. [43] demonstrated that the hawk moths Deilephila elpenor (L.), Hyles lineata (F.), and Hyles gallii (Rottemburg) (Lepidoptera: Sphingidae) use color vision to discriminate between flowers at night. The significant influence of high-reflectance-energy-colored traps on adult male captures has also been reported for T. pityocampa [26].

Although no significant differences were recorded among the examined trap heights, seasonal differences were observed at individual dates. These seasonal differences in captures may be either related to the seasonal changes of the growth of the cotton plants and their fruiting organs or to the population fluctuations of the insect. Priyanka et al. [33] found that traps placed at canopy level in pigeon-pea cultivation gathered a higher number of male adults of $H$. armigera than the traps that were placed one and two feet above and below the canopy level. The seasonality of the captures of H. armigera at traps placed at different heights has been also reported by Ujjan et al. [29], who observed the highest catches at chickpea crops in traps placed at 6 feet $(183 \mathrm{~cm})$ during the crop season and at 4 feet $(122 \mathrm{~cm})$ after harvest. Early in the experimental period, when the plants had smaller heights, we noticed that on some of the trap-check dates, relatively higher captures were recorded in traps that were placed at $30 \mathrm{~cm}$ than at 60 and $90 \mathrm{~cm}$, while later in the growing season, the traps at this height had lower capture numbers compared to the other heights.

The pheromone agent, in the sense of a commercially available pheromone capsule formulation, has been found to be an important factor in H. armigera adult captures. However, our data show that all three formulations provided a similar population fluctuation pattern of $H$. armigera. This is especially important, as the indication of generations is a top priority in the management of this species, especially at the time of the appearance of the cotton bolls. Hence, despite differences in the captures, the "synchronization" of the different trap categories in estimating the time of the increase in $H$. armigera adult numbers is of fundamental importance, in order to accurately time the insecticidal applications. Similar results have been reported in the case of the pink bollworm, Pectinophora gossypiella (Saunders) (Lepidoptera: Gelechiidae), where different pheromone levels provided a similar estimation of the occurrence of the generations [24].

In conclusion, this study shows that trap color and pheromone formulation are characteristics that strongly affect the response of H. armigera males to pheromone-baited traps. Hence, specific trap colors and pheromone lures were found to be more effective than others, while trap height played a less-important role. These findings should be taken into account when developing a monitoring system, which should be standardized and provide results that reliably depict $H$. armigera populations, which is particularly critical in the case of area-wide management protocols. 
Author Contributions: Conceptualization, C.I.R. and C.G.A.; methodology, A.K. and E.L.; validation, C.G.A.; formal analysis, E.L.; investigation, A.K.; data curation, A.K., and E.L. writing-original draft preparation, A.K., E.L., C.I.R. and C.G.A.; writing-review and editing, A.K., E.L. and C.G.A. supervision, E.L., C.I.R. and C.G.A.; project administration, C.G.A. All authors have read and agreed to the published version of the manuscript.

Funding: This research received no external funding.

Data Availability Statement: Data is contained within the article.

Conflicts of Interest: The authors declare no conflict of interest.

\section{References}

1. Fitt, G.P. The ecology of Heliothis species in relation to agro-ecosystems. Annu. Rev. Entomol. 1989, 34, 17-52. [CrossRef]

2. Common, I.F.B. The Australian species Heliothis (Lepidoptera: Noctuidae) and their pest status. Aust. J. Zool. 1953, 1, 319-344. [CrossRef]

3. Pearson, E.O. The Insect Pests of Cotton in Tropical Africa; Commonwealth Institute of Entomology: London, UK, $1958 ;$ p. 335.

4. Reed, W.; Kumble, V. In Proceedings of the International Workshop on Heliothis Management. Patancheru, India, 15-20 November 1981; ICRISAT: Patancheru, India, 1982; p. 418.

5. Wardhaugh, K.G.; Room, P.M.; Greenup, L.R. The incidence of Heliothis armigera (Hubner) and H. punctigera Wallengren (Lepidoptera: Noctuidae) on cotton and other host plants in the Namoi Valley of New South Wales. Bull. Entomol. Res. 1980, 70, 113-131. [CrossRef]

6. Zalucki, M.P.; Daglish, G.; Firempong, S.; Twine, P. The biology and ecology of Heliothis armigera (Hubner) and H. punctigera Wallengran (Lepidoptera: Noctuidae) in Australia: What do we know? Aust. J. Zool. 1986, 34, 779-814. [CrossRef]

7. Pogue, M.G. A new synonym of Helicoverpa zea (Boddie) and differentiation of adult males of H. zea and H. armigera (Hubner) (Lepidoptera: Noctuidae: Heliothinae). Ann. Entomol. Soc. Am. 2004, 97, 1222-1226. [CrossRef]

8. Mironidis, G.K.; Stamopoulos, D.C.; Savopoulou-Soultani, M. Overwintering survival and spring emergence of Helicoverpa armigera (Lepidoptera: Noctuidae) in northern Greece. Environ. Entomol. 2010, 39, 1068-1084. [CrossRef]

9. Farrer, R.R.; Bradley, J.R. Within-plant distribution of Heliothis spp. (Lepidoptera: Noctuidae) eggs and larvae on cotton in North Carolina. Environ. Entomol. 1985, 14, 205-209. [CrossRef]

10. Lammers, L.; Macleod, A.; Loomans, A.; Van Der Straten, M.; Cannon, R.; Eyre, D.; Baker, R. Report of a Pest Risk Analysis: Helicoverpa armigera (Hübner, 1808); Plant of Protection Service: Wageningen, The Netherlands; Central Science Laboratory: North Yorkshire, UK, 2007; p. 18.

11. Srivastava, C.P.; Joshi, N.; Trivedi, T.P. Forecasting of Helicoverpa armigera populations and impact of climate change. Indian J. Agric. Sci. 2010, 80, 3-10.

12. Armes, N.J.; Jadhav, D.R.; Bond, G.S.; King, A.B.S. Insecticide resistance in Helicoverpa armigera in South India. J. Pestic. Sci. 1992, 34, 355-364. [CrossRef]

13. Armes, N.J.; Jadhav, D.R.; DeSouza, K.R. A survey of insecticide resistance in Helicoverpa armigera in the Indian subcontinent. Bull. Entomol. Res. 1996, 86, 499-514. [CrossRef]

14. Venugopal, R.N.; Raja Sekhar, P.; Venkataiah, M.; Rajasri, M. Estimation of insecticide resistance in H. armigera (Hubner) in Andhra pradesh. Indian J. Pl. Prot. 1994, 22, 33-37.

15. Sekhar Raja, P.; Venkataiah, M.; Venugopal Rao, N.; Rama Rao, B.; Prakash Rao, V.S. Monitoring of insecticide resistance in Helicoverpa armigera (Hubner) from areas receiving heavy insecticidal applications in Andhra Pradesh (India). J. Entomol. Res. 1996, 20, 93-102.

16. Perini, C.R.; Arnemann, J.A.; Melo, A.A.; Pes, M.P.; Valmorbida, I.; Beche, M.; Guedes, J.V.C. How to control Helicoverpa armigera in soybean in Brazil? What we have learned since its detection. Afr. J. Agric. Res. 2016, 11, 1426-1432.

17. Durigan, M.R.; Corrêa, A.S.; Pereira, R.M.; Leite, N.A.; Amado, D.; de Sousa, D.R.; Omoto, C. High frequency of CYP337B3 gene associated with control failures of Helicoverpa armigera with pyrethroid insecticides in Brazil. Pestic. Biochem. Physiol. 2017, 143, 73-80. [CrossRef]

18. Durigan, M.R. Resistance to Pyrethroid and Oxadiazine Insecticides in Helicoverpa armigera (Lepidoptera: Noctuidae) Populations in Brazil. Ph.D. Thesis, University of Sao Paulo, ESALQ, Piracicaba, Brazil, 2018.

19. Kumar, M.; Sharma, P.K.; Sharma, A.K. Studies on pheromone catches of Helicoverpa armigera Hubner and relation of moth activity with larval infestation on tomato in Baghpat, Uttar Pradesh. Int. J. Microb. Resour. Technol. 2013, 2, $2278-3822$.

20. Pal, S.; Chatterjee, H.; Senapati, S.K. Monitoring of Helicoverpa armigera using pheromone traps and relationship of moth activity with larval infestation on carnation (Dianthus caryophyllus) in Darjeeling Hills. J. Entomol. Res. 2014, 38, 23-26.

21. Reddy, S.G.E.; Rana, S.; Rana, A.; Kumar, R. Seasonal incidence and monitoring of Helicoverpa armigera Hübner on damask rose (Rosa $\times$ damascena Herrm.) by sex pheromone traps in western Himalaya (India). J. Appl. Res. Med. Aroma. 2021, $20,100270$. [CrossRef]

22. Sah, L.N.; Sahu, R.; Neupana, F.P. Monitoring the chickpea pod borer, Heliothis armigera by a pheromone trap. J. Inst. Agric. Anim. Sci. 1988, 9, 107-109. 
23. Sage, T.L.; Gregg, P.C. A comparison of four types of pheromone traps for Heliothis armigera (Hubner) (Lepidoptera: Noctuidae). Aust. J. Entomol. 1985, 24, 99-100. [CrossRef]

24. Athanassiou, C.G.; Kavallieratos, N.G.; Gravanis, F.T.; Koukounitsas, N.A.; Roussou, D.E. Influence of trap type, pheromone quantity and trapping location on capture of the pink bollworm, Pectinophora gossypiella (Saunders) (Lepidoptera: Gelechiidae). Appl. Entomol. Zool. 2002, 37, 385-391. [CrossRef]

25. Athanassiou, C.G.; Kavallieratos, N.G.; Mazomenos, B.E. Effect of trap type, trap color, trapping location, and pheromone dispenser on captures of male Palpita unionalis (Lepidoptera: Pyralidae). J. Econ. Entomol. 2004, 97, 321-329. [CrossRef] [PubMed]

26. Athanassiou, C.G.; Kavallieratos, N.G.; Gakis, S.F.; Kyrtsa, L.A.; Mazomenos, B.E.; Gravanis, F.T. Influence of trap type, trap colour, and trapping location on the capture of the pine moth, Thaumetopoea pityocampa. Entomol. Exp. Appl. 2006, 122, 117-123. [CrossRef]

27. Kavallieratos, N.G.; Athanassiou, C.G.; Balotis, G.N.; Tatsi, G.T.; Mazomenos, B.E. Factors affecting male Prays oleae (Lepidoptera: Yponomeutidae) captures in pheromone-baited traps in olive orchards. J. Econ. Entomol. 2005, 98, 1499-1505. [CrossRef] [PubMed]

28. Guerrero, S.; Brambila, J.; Meagher, R.L. Efficacies of four pheromone-baited traps in capturing male Helicoverpa (Lepidoptera: Noctuidae) moths in Northern Florida. Fla. Entomol. 2014, 97, 1671-1678. [CrossRef]

29. Ujjan, R.L.; Ahmed, A.M.; Alhilfi, A.Z.A.; Khoso, F.N.; Rahoo, A.M.; Rajput, I.A.; Soomro, D.M. Performance of pheromone traps at different heights for mass trapping of Helicoverpa armigera (Noctuidae: Lepidoptera) in chickpea field. Asian J. Agric. Biol. 2019, 7,610-616.

30. Hashemi, S.M. Influence of pheromone trap color and placement on catch of male potato tuber moth, Phthorimaea operculella (Zeller, 1873). Ecol. Balk. 2015, 7, 45-50.

31. Raman, K.V. Control of potato tuber moth Phthorimaea operculella with sex pheromones in Peru. Agric. Ecosyst. Environ. 1988, 21, 85-99. [CrossRef]

32. Witzgall, P.; Kirsch, P.; Giri, S.K. Monitoring of gram pod borer, Helicoverpa armigera through pheromone traps on pigeon pea (Cajanus cajan (L.) Millsp.). Legum. Res. 2016, 5, 524-535.

33. Priyanka, L.S.; Saminathan, V.R.; Sithanantham, S.; Ambethgar, V.; Manivannan, N. Evaluation of pheromone traps for the management of pod borer, Helicoverpa armigera (Hubner) in Redgram [Cajanus cajan (L.) Millsp.] ecosystem. Res. Biot. 2020, 2, $8-10$.

34. Ryan, M.F. Pheromone in plant protection. In Insect Chemoreception Fundamental and Applied; Kluwer Academic Publishers: Dordrecht, The Netherlands, 2002; pp. 256-279.

35. Adams, R.G.; Murray, K.D.; Los, L.M. Effectiveness and selectivity of seven pheromone lures and traps for monitoring fall armyworm (Lepidoptera; Noctuidae) adults in Connecticut sweet corn. J. Econ. Entomol. 1989, 82, 285-290. [CrossRef]

36. Gauthier, N.L.; Logan, P.A.; Twekspury, L.A.; Hollingsworth, C.F.; Weber, D.C.; Adams, R.C. Field bioassay of pheromone lure and trap designs for monitoring adult corn earworm in sweet corn at southern England. J. Econ. Entomol. 1991, 84, 1833-1836. [CrossRef]

37. USDA Foreign Agricultural Service. Greece: Cotton and Products Annual; No. IT1806; Gain Report; Global Agricultural Information Network: Washington, DC, USA, 2018.

38. Mourikis, P.A.; Vasilaina-Alexopoulou, P. Notes on the rearing on the synthetic diet of the cotton bollworm Heliothis armigera. Annls. Inst. Phytopath. Benaki 1969, 9, 46-53.

39. Stavridis, D.G.; Gliatis, A.; Deligeorgidis, P.N.; Giatropoulos, C.; Giatropoulos, A.; Deligeorgidis, N.P.; Ipsilandis, C.G. Cotton production in the presence of Helicoverpa armigera (Hb.) in Central Greece. Pak. J. Biol. Sci. 2008, 11, 2490-2494. [CrossRef] [PubMed]

40. Baker, G.H.; Tann, C.R.; Fitt, G.P. A tale of two trapping methods: Helicoverpa spp. (Lepidoptera, Noctuidae) in pheromone and light traps in Australian cotton productions systems. Bull. Entomol. Res. 2011, 101, 9-23. [CrossRef]

41. Nyambo, B.T. Assessment of pheromone traps for monitoring and early warning of Heliothis armigera Hübner (Lepidoptera, Noctuidae) in the western cotton-growing areas of Tanzania. Crop Prot. 1989, 8, 188-192. [CrossRef]

42. Shinde, Y.A.; Patel, B.R.; Mulekar, V.G. Seasonal incidence of gram caterpillar, Helicoverpa armigera (Hub.) in chickpea. Curr. Biot. 2013, 7, 79-82.

43. Kelber, A.; Balkenius, A.; Warrant, E.J. Scotopic color vision in nocturnal hawkmoths. Nature 2002, 419, 922-925. [CrossRef] 